\title{
Clarity of Anatomic Information: Comparison of Variations in Combination of Time Repetition (TR) and Echo Train Length (ETL) MRI Lumbar Sequence T2W Turbo Spin Echo in the Diagnosis of Low Back Pain
}

\author{
* $1^{\text {st }}$ Rini Indrati \\ Radiodiagnostic and Radiotherapy \\ Poltekkes Kemenkes Semarang \\ Semarang, Indonesia \\ riniindrati@poltekkes-smg.ac.id \\ $4^{\text {th }}$ Emi Murniati \\ Radiodiagnostic and Radiotherapy \\ Poltekkes Kemenkes Semarang \\ Semarang, Indonesia \\ emimurniati@ymail.com
}

\author{
$2^{\text {nd }}$ Lies Mardiyana \\ Medicine Faculty \\ Universitas Airlangga \\ Surabaya, Indonesia \\ lies.mardiyana@fkunair.ac.id \\ $5^{\text {th }}$ Siti Daryati \\ Radiodiagnostic and Radiotherapy \\ Poltekkes Kemenkes Semarang \\ Semarang, Indonesia \\ sitidaryati@yahoo.co.id
}

\author{
$3^{\text {rd }}$ Ainul Amarudin \\ Radiology Department \\ $d r$. Ramelan Hospital \\ Surabaya, Indonesia \\ luthfiefde@gmail.com \\ $6^{\text {th }}$ Sri Mulyati \\ Radiodiagnostic and Radiotherapy \\ Poltekkes Kemenkes Semarang \\ Semarang, Indonesia \\ cici.mulyadi@gmail.com \\ $7^{\text {th }}$ Dwi Rochmayanti \\ Radiodiagnostic and Radiotherapy \\ Poltekkes Kemenkes Semarang \\ Semarang, Indonesia \\ dwirochmayanti@poltekkes-smg.ac.id
}

\begin{abstract}
Time Repetition (TR) and Echo Train Length (ETL) are the parameters in MRI that can be adjusted by a radiographer to affect image quality, anatomic information, and scan time. There are various TR and ETL adjustments used for lumbar MR imaging. This study is to determine the differences in the combination of TR and ETL to the anatomic information of the images. This is an experimental research. Data were collected from 30 patients with variations of $\mathbf{T R}_{\mathbf{1 0 0 0}}$, TR $_{2000}$, ETL $_{13}$, ETL $_{17}$, and ETL $L_{21}$. The Images were evaluated by radiologists. Evaluation of the images were conducted on the corpus vertebrae, inter vertebral disc, conus medullar, cerebrospinal fluid and ligamentum flavum. The data were analyzed using Friedman test with $\mathbf{9 5 \%}$ CI. The results show that the combination of TR and ETL variations affect the anatomic information of T2WI TSE sagittal lumbar MRI. The Friedman test shows differences of image anatomic information from variations of the combination of TR and ETL (p-value $=0.001)$. The Combination of $\mathbf{T R}_{2000}$ ETL $_{17}$ produces optimal image information.
\end{abstract}

Keywords-MRI Lumbar sagittal, T2W TSE, variation of TR and ETL

\section{INTRODUCTION}

Low back pain (LBP) is a common complaint. Nearly $70 \%-80 \%$ of the population in developed countries have experienced LBP. Low back pain is pain that is confined to the lumbar region, but the symptoms are more evenly distributed and are not limited to one nerve root but are broadly derived from the lumbar intervertebral disc[1]. Low
Back Pain is usually caused by the compression of paravertebral muscles, herniation and regeneration of the nucleus pulposus, osteoarthritis of the spine[2],[3]. Abnormalities in lumbar can be identified with a variety of radiological examinations, namely conventional X-Ray, CT Scan and MRI[3]. One of the examination techniques in diagnosing LBP is using Magnetic Resonance Imaging (MRI) of the lumbar. MRI can examine the corpus vertebrae, intervertebral discs, conus medullar, ligamentum flavum and Cerebrospinal Fluid in the Lumbar region that cannot be seen using ordinary X-ray or Computerized Tomography[3],[4].

Patients with complaints of pain in the spines are usually unable to lie down on their backs for long periods of time so a fast scan is needed with good anatomic image information. The best MRI images can be obtained through certain setting sequences and parameters in MRI. One of the MRI sequences used in Lumbar MRI examination is T2 Weighted Spin Echo sequence (T2W SE). T2W SE requires a long scan time, so it is often combined with the turbo factor/TSE factor parameter to T2W TSE to reduce the scan time[4],[5].

Several ways to reduce scan time on lumbar MRI with T2W TSE sequence are by making changes to the value of Time Repetition (TR) and Echo Train Length (ETL)/TSE factor/Turbo factor. Time Repetition (TR) is the primary parameter, which also includes Time Echo (TE), Time Inversion (TI) and Flip Angle (FA) which affect the image contrast [6][7][8]. 
The image quality of MRI is influenced by several factors, namely: (1) Signal to Noise Ratio (SNR), which is the ratio between the amount of signal amplitude and noise amplitude; (2) Contrast to Noise Ratio (CNR), which is the difference in SNR between the closest organs; (3) spatial resolution, which is the size of the acquisition matrix controlling image resolution and (4) scan time[9],[10].

Turbo Spin Echo (TSE) is one of the developments of the Spin Echo sequence. Using TSE sequence has the same advantage as using spin echo but the scan time is much shorter [12],[13]. This is widely used for T2 weighted images because of the reduced use of time. In TSE, scan time is reduced by having more than one phase encode per TR, known as Echo Train Length (ETL). The value of ETL or turbo factor that can be used ranges from 2 to 32 [16],[17]. TSE sequences are used to obtain optimal image quality in relatively short scan time [16],[17]. Application of a longer TR can examine the tissues in more slices and provide better signal values, but this will result in extended time of image acquisition. Fast TR can shorten data collection time but the number of tissue slices being examined is smaller and the Signal to Noise Ratio (SNR) is lower [18].

\section{METHOD}

This research is an experimental research with one shot post-test method only with control group design. The purpose of this study is to determine differences in anatomic information on MRI images of lumbar sagittal slices of T2W TSE sequence from variations in the combination of TR and ETL settings and to determine the appropriate values of TR and ETL combination to produce the best anatomic image information and scan time. The sample consists of 30 patients suffering from LBP having a normal form of lumbar morphology. The assessment of visual image information has been performed by Radiology specialists to determine the anatomic clarity of lumbar MRI images including the corpus vertebrae, intervertebral discs, conus medullar, cerebrospinal fluid and ligamentum flavum. Patients agreed to participate in the study after giving informed consent. Ethical Clearance was obtained from the AL Hospital's Ethic Commission Dr. Ramelan Surabaya. The data were analyzed using Friedman test at a magnitude of $95 \%$. The parameters used in the lumbar MRI T2W TSE in this study were TR $=1000 \mathrm{~ms}$ and $2000 \mathrm{~ms}$, ETL / TSE Factor 13, 17 and 21, TE $100 \mathrm{~ms}$, NSA 1, Slice Thickness of $4 \mathrm{~mm}$, FOV 180 × $300 \mathrm{~mm}$, Flip Angle $90^{\circ}$, Bandwidth $181 \mathrm{kHz}$. The research design is as follows:

\section{Sample $\stackrel{\mathrm{X}_{1} \mathrm{X}_{2} \mathrm{X}_{3} \mathrm{X}_{4} \mathrm{X}_{5} \mathrm{X}_{6}}{\longrightarrow} \mathrm{O}_{1} \mathrm{O}_{2} \mathrm{O}_{3} \mathrm{O}_{4} \mathrm{O}_{5} \mathrm{O}_{6}$}

with :

$\mathrm{X} 1=$ Intervention with combination $\mathrm{TR}_{1000}-\mathrm{ETL}_{13}$

$\mathrm{X} 2=$ Intervention with combination $\mathrm{TR}_{1000}-\mathrm{ETL}_{17}$

$\mathrm{X} 3=$ Intervention with combination $\mathrm{TR}_{1000}-\mathrm{ETL}_{21}$

$\mathrm{X} 4=$ Intervention with combination $\mathrm{TR}_{2000}-\mathrm{ETL}_{13}$

$\mathrm{X} 5=$ Intervention with combination $\mathrm{TR}_{2000}-\mathrm{ETL}_{17}$

$\mathrm{X} 6=$ Intervention with combination $\mathrm{TR}_{2000}-\mathrm{ETL}_{21}$

$\mathrm{O} 1=$ Anatomical information of combination $\mathrm{TR}_{1000}-\mathrm{ETL}_{13}$

$\mathrm{O} 2=$ Anatomical information of combination $\mathrm{TR}_{1000}-\mathrm{ETL}_{17}$

$\mathrm{O} 3=$ Anatomical information of combination $\mathrm{TR}_{1000}-\mathrm{ETL}_{21}$
$\mathrm{O} 4=$ Anatomical information of combination $\mathrm{TR}_{2000}-\mathrm{ETL}_{13}$ $\mathrm{O} 5=$ Anatomical information of combination $\mathrm{TR}_{2000}-\mathrm{ETL}_{17}$ $\mathrm{O} 6=$ Anatomical information of combination $\mathrm{TR}_{2000}-\mathrm{ETL}_{21}$

The Clarity of Lumbar Anatomic Information assessed consists 5 parts as shown in Figure 1.

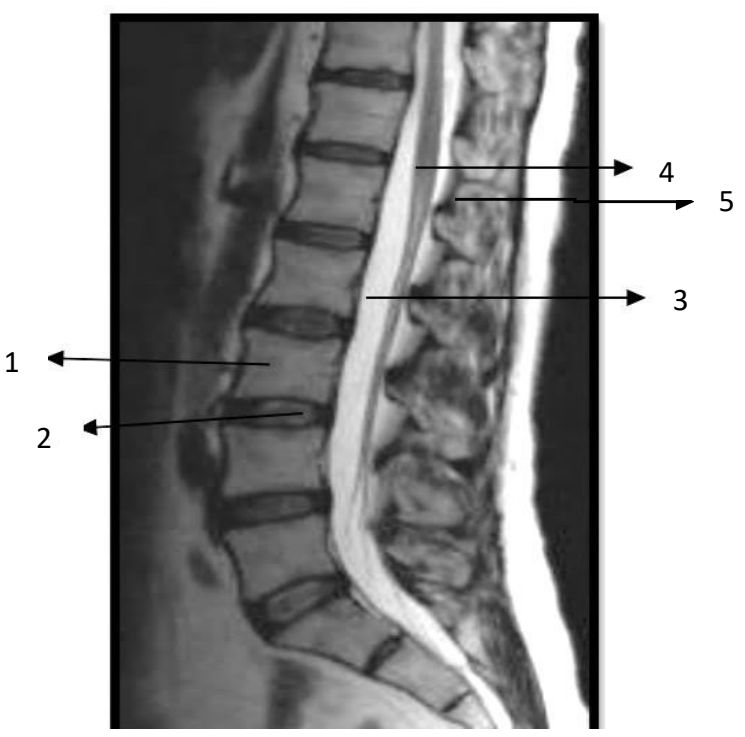

Fig. 1. Anatomy of Lumbar Sagittal MRI T2 TSE[20][21][22]

1. Corpus vertebrae,

2. Intervertebral disc

3. Cerebrospinal fluid,

4. Conus medullar

5. ligamentum flavum

\section{RESULT AND DISCUSSION}

\section{A. Result}

The images result from variations in the combination of TR and ETl are shown in Figure 2.

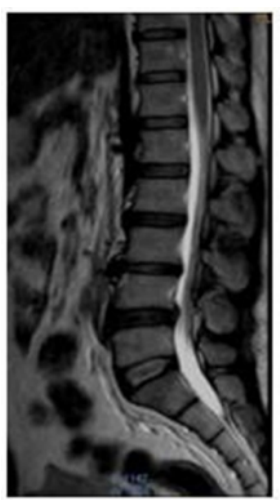

$\mathrm{TR}_{1000} \mathrm{ETL}_{13}$

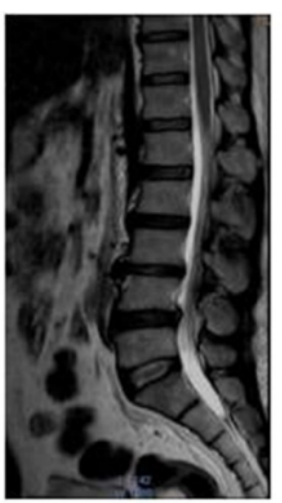

$\mathrm{TR}_{1000} \mathrm{ETL}_{17}$

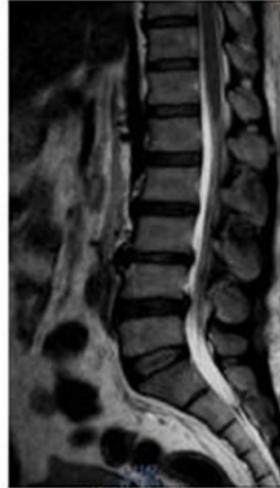

$\mathrm{TR}_{1000} \mathrm{ETL}_{21}$ 


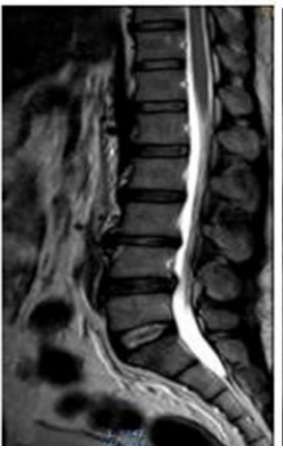

$\mathrm{TR}_{2000} \mathrm{ETL}_{13}$

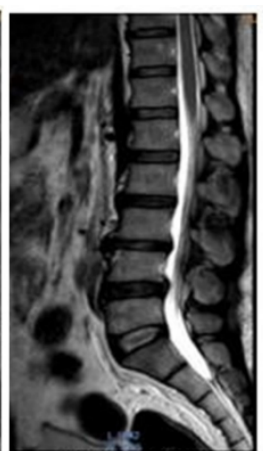

$\mathrm{TR}_{2000} \mathrm{ETL}_{17}$

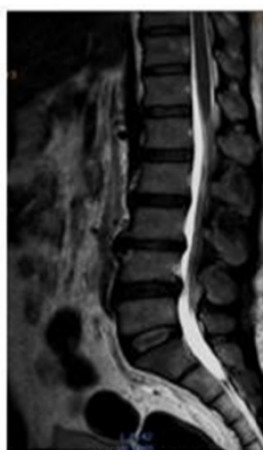

$\mathrm{TR}_{2000} \mathrm{ETL}_{21}$
Fig. 2. Lumbar MRI images with various combinations of TR and ETL values on sagittal slices

Six (6) images have been obtained as the results of Lumbar MRI Scanning with HNP cases with variations in the combination of TR and ETL values shown in Figure 1. The images obtained result from 6 variations of the value of the combination of $\mathrm{TR}_{1000}$ and $\mathrm{ETL}_{13}, \mathrm{TR}_{1000}-\mathrm{ETL}_{17}, \mathrm{TR}_{1000-}$ ETL21，TR2000-ETL13， TR2000-ETL17， TR2000-ETL21. The choice of the variation is based on the range of TR and ETL values that are commonly used in Lumbar MRI in the clinics. Of the 30 patients who became the objects of the study, 21 were male and 9 were female with the ages ranging from 21 to 65 years. The results of the radiology specialist's assessment of the anatomic image clarity went through the conformity perception test, the results are shown in table 1.

TABLE I. THE RESULTS FOR CONFORMITY PERCEPTION TEST ON THE ASSESSMENT OF CLARITY OF LUMBAR ANATOMIC INFORMATION

\begin{tabular}{lll}
\hline Respondent & Koeff. Kappa & p-value \\
\hline R-1 vs R-2 & 0.845 & $<0.001$ \\
\hline
\end{tabular}

Table 1. shows that there is a good conformity perception between the two observers regarding the anatomic clarity of with Kappa coefficient $=0.845$ (p-value $<0.001)$.

Test results for differences in clarity of lumbar MRI anatomic information on the variation of the TR and ETL combination of the T2W TSE sequence using the FriedmanTest are shown in table 2 .

TABLE II. TEST RESULTS FOR DIFFERENCES IN CLARITY OF LUMBAR MRI ANATOMIC INFORMATION ON THE VARIATIONS IN THE COMBINATION OF TR AND ETL

\begin{tabular}{cccc}
\hline Variable & Mean Rank & $\begin{array}{c}\text { Scan Time } \\
\text { (minutes) }\end{array}$ & p-value \\
\hline TR $_{1000}$ ETL $_{13}$ & 3.11 & 2,36 & \\
TR $_{1000}$ ETL $_{17}$ & 3.26 & 2,00 & \\
TR $_{1000}$ ETL $_{21}$ & 2.87 & 1,40 & 0.001 \\
RR $_{2000}$ ETL $_{13}$ & 4.00 & 2,32 & \\
TR $_{2000}$ ETL $_{17}$ & 4.53 & 1,56 & \\
TR $_{2000}$ ETL $_{21}$ & 3.11 & 2,36 & \\
\hline
\end{tabular}

The test on differences of anatomic information clarity with Friedman test showed that there are differences in anatomic information clarity between variations in the combination of TR and ETL with p-value $=0.001$. The clearest anatomic information was obtained from the use of a combination of $\mathrm{TR}_{2000}$ and $\mathrm{ETL}_{17}$ with the highest mean Rank $=4.53$, while the combination of TR and ETL that produced the lowest clarity of anatomic information is $\mathrm{TR}_{1000}$ with $\mathrm{ETL}_{13}$ with the smallest mean rank $=3.11$. The longest scan time took place in the use of a combination of $\mathrm{TR}_{1000}$ with ETL 13 , with the scan time of 2.36 minutes. While the fastest scan time resulted from the use of a combination of $\mathrm{TR}_{2000}$ with ETL 21 with a scan time of 1.36 minutes.

To find out more about the differences in anatomic clarity between the combination of TR and ETL, the Wilcoxon test was conducted, and the results are shown in Table 3.

TABLE III. TEST RESULTS ON THE DIFFERENCES IN LUMBAR MRI IMAGE ANATOMIC INFORMATION BETWEEN VARIATIONS IN THE COMBINATION OF TR AND ETL WITH THE WILCOXON TEST

\begin{tabular}{|c|c|}
\hline Combination of TR dan ETL & p-value \\
\hline $\mathrm{TR}_{1000}-\mathrm{ETL}_{13}$ vs $\mathrm{TR}_{1000}-\mathrm{ETL}_{17}$ & 0.519 \\
\hline $\mathrm{TR}_{1000}-\mathrm{ETL}_{13}$ vs $\mathrm{TR}_{1000}-\mathrm{ETL}_{21}$ & 0.297 \\
\hline $\mathrm{TR}_{1000}-\mathrm{ETL}_{13}$ vs $\mathrm{TR}_{2000}-\mathrm{ETL}_{13}$ & $<0.001$ \\
\hline $\mathrm{TR}_{1000}-\mathrm{ETL}_{13}$ vs $\mathrm{TR}_{2000}-\mathrm{ETL}_{17}$ & $<0.001$ \\
\hline $\mathrm{TR}_{1000}-\mathrm{ETL}_{13}$ vs $\mathrm{TR}_{2000}-\mathrm{ETL}_{21}$ & 0.637 \\
\hline $\mathrm{TR}_{1000}-\mathrm{ETL}_{17}$ vs TR $1000-\mathrm{ETL}_{21}$ & 0.101 \\
\hline $\mathrm{TR}_{1000}-\mathrm{ETL}_{17}$ vs $\mathrm{TR}_{2000}-\mathrm{ETL}_{13}$ & 0.001 \\
\hline $\mathrm{TR}_{1000}-\mathrm{ETL}_{17}$ vs $\mathrm{TR}_{2000}-\mathrm{ETL}_{17}$ & $<0.001$ \\
\hline $\mathrm{TR}_{1000}-\mathrm{ETL}_{17}$ vs TR $2000-\mathrm{ETL}_{21}$ & 0.827 \\
\hline $\mathrm{TR}_{1000}-\mathrm{ETL}_{21}$ vs $\mathrm{TR}_{2000}-\mathrm{ETL}_{13}$ & $<0.001$ \\
\hline $\mathrm{TR}_{1000}-\mathrm{ETL}_{21}$ vs TR $2000-\mathrm{ETL}_{17}$ & $<0.001$ \\
\hline $\mathrm{TR}_{1000}-\mathrm{ETL}_{21}$ vs $\mathrm{TR}_{2000}-\mathrm{ETL}_{21}$ & 0.108 \\
\hline $\mathrm{TR}_{2000}-\mathrm{ETL}_{13}$ vs $\mathrm{TR}_{2000}-\mathrm{ETL}_{17}$ & 0.248 \\
\hline $\mathrm{TR}_{2000}-\mathrm{ETL}_{13}$ vs TR $2000-\mathrm{ETL}_{21}$ & $<0.001$ \\
\hline $\mathrm{TR}_{2000}-\mathrm{ETL}_{17}$ vs $\mathrm{TR}_{2000}-\mathrm{ETL}_{21}$ & $<0.001$ \\
\hline
\end{tabular}

Different test results between variations in the combination of TR and ETL with the Wilcoxon-test showed that there are significant differences in the clarity of anatomic information on Lumbar MRI Lumbar T2 TSE sagittal slices between variations in the combination of $\mathrm{TR}_{1000}-\mathrm{ETL}_{13}$ with $\mathrm{TR}_{2000}-\mathrm{ETL}_{13}$ (p-value $<0.001$ ), $\mathrm{TR}_{1000}$ ETL $_{13}$ with TR $_{2000}-$ ETL $_{17}$ (p-value $<0.001$ ), TR $_{1000}-E_{17}$ with $\mathrm{TR}_{2000} \mathrm{ETL}_{13}$ (p-value $\left.=0.001\right), \mathrm{TR}_{1000} \mathrm{ETL}_{21}$ with $\mathrm{TR}_{2000}-\mathrm{ETL}_{13}$ (p-value $<0.001$ ), $\mathrm{TR}_{2000}-\mathrm{ETL}_{13}$ with $\mathrm{TR}_{2000}$ $\mathrm{ETL}_{21}$ (p -value $<0.001$ and TR2000-ETL17 with TR2000-ETL21 ( $p$-value $<0.001)$. The test results show no difference in the anatomic information on lumbar MRI T2W TSE sagittal slices between variations in the combination of TR $1000-\mathrm{ETL}_{13}$ and $\mathrm{TR}_{1000}-\mathrm{ETL}_{17}$ (p-value $=0.519$ ), $\mathrm{TR}_{1000}-\mathrm{ETL}_{13}$ with $\mathrm{TR}_{1000}-\mathrm{ETL}_{21}(\mathrm{p}$-value $=0.297), \mathrm{TR}_{1000}-\mathrm{ETL}_{13}$ with $\mathrm{TR}_{2000}$ $\mathrm{ETL}_{21}$ (p-value $\left.=0.637\right), \mathrm{TR}_{1000}-\mathrm{ETL}_{17}$ with $\mathrm{TR}_{1000}-\mathrm{ETL}_{21}$ $(\mathrm{p}$-value $=0.101), \mathrm{TR}_{1000}-\mathrm{ETL}_{21} \mathrm{ETL}_{17}$ with TR $\mathrm{TR}_{2000}-\mathrm{ETL}_{21}(\mathrm{p}-$ value $=0.827), \mathrm{TR}_{1000}-\mathrm{ETL}_{21}$ with $\mathrm{TR}_{2000}-\mathrm{ETL}_{21}(\mathrm{p}$-value $=$ 0.108 ) and between $\mathrm{TR}_{2000}-\mathrm{ETL}_{13}$ and $\mathrm{TR}_{2000}-\mathrm{ETL}_{17}$ (p-value $=0.248)$.

Difference test results with the Friedman test to determine differences in anatomic clarity of each lumbar section are shown in table 4.

TABLE IV. TEST RESULTS ON DIFFERENCES IN THE CLARITY OF ANATOMIC INFORMATION THE LUMBAR T2 TSE MRI ON VARIATIONS OF TR AND ETL COMBINATIONS

\begin{tabular}{cccc}
\hline Anatomy & Variation & p-value & Mean rank \\
\hline & TR $_{1000}$ ETL $_{13}$ & & 2.80 \\
& RR $_{1000}$ ETL $_{17}$ & & 2.80 \\
Corpus vertebrae & TR $_{1000}$ ETL $_{21}$ & 0.010 & 3.10 \\
& TR $_{2000}$ ETL $_{13}$ & & 3.40 \\
& TR $_{2000}$ ETL $_{17}$ & & 4.60
\end{tabular}




\begin{tabular}{|c|c|c|c|}
\hline & $\mathrm{TR}_{2000} \mathrm{ETL}_{21}$ & & 4.30 \\
\hline \multirow{6}{*}{$\begin{array}{c}\text { Discus } \\
\text { intervertebral }\end{array}$} & $\mathrm{TR}_{1000} \mathrm{ETL}_{13}$ & \multirow{6}{*}{$<0.001$} & 3.35 \\
\hline & $\mathrm{TR}_{1000} \mathrm{ETL}_{17}$ & & 2.45 \\
\hline & $\mathrm{TR}_{1000} \mathrm{ETL}_{21}$ & & 2.45 \\
\hline & $\mathrm{TR}_{2000} \mathrm{ETL}_{13}$ & & 4.85 \\
\hline & $\mathrm{TR}_{2000} \mathrm{ETL}_{17}$ & & 4.85 \\
\hline & $\mathrm{TR}_{2000} \mathrm{ETL}_{21}$ & & 3.05 \\
\hline \multirow{6}{*}{ Conus Medullar } & $\mathrm{TR}_{1000} \mathrm{ETL}_{13}$ & \multirow{6}{*}{0.016} & 2.55 \\
\hline & $\mathrm{TR}_{1000} \mathrm{ETL}_{17}$ & & 4.15 \\
\hline & $\mathrm{TR}_{1000} \mathrm{ETL}_{21}$ & & 3.75 \\
\hline & $\mathrm{TR}_{2000} \mathrm{ETL}_{13}$ & & 3.40 \\
\hline & $\mathrm{TR}_{2000} \mathrm{ETL}_{17}$ & & 4.60 \\
\hline & $\mathrm{TR}_{2000} \mathrm{ETL}_{21}$ & & 2.55 \\
\hline \multirow{6}{*}{$\begin{array}{l}\text { Cerebrospinal } \\
\text { Fluids }\end{array}$} & $\mathrm{TR}_{1000} \mathrm{ETL}_{13}$ & \multirow{6}{*}{0,012} & 3.35 \\
\hline & $\mathrm{TR}_{1000} \mathrm{ETL}_{17}$ & & 4.00 \\
\hline & $\mathrm{TR}_{1000} \mathrm{ETL}_{21}$ & & 2.15 \\
\hline & $\mathrm{TR}_{2000} \mathrm{ETL}_{13}$ & & 4.00 \\
\hline & $\mathrm{TR}_{2000} \mathrm{ETL}_{17}$ & & 3.95 \\
\hline & $\mathrm{TR}_{2000} \mathrm{ETL}_{21}$ & & 3.55 \\
\hline \multirow{6}{*}{$\begin{array}{l}\text { Ligamentum } \\
\text { flavum }\end{array}$} & $\mathrm{TR}_{1000} \mathrm{ETL}_{13}$ & \multirow{6}{*}{0,001} & 3.50 \\
\hline & $\mathrm{TR}_{1000} \mathrm{ETL}_{17}$ & & 2.90 \\
\hline & $\mathrm{TR}_{1000} \mathrm{ETL}_{21}$ & & 2.90 \\
\hline & $\mathrm{TR}_{2000} \mathrm{ETL}_{13}$ & & 4.35 \\
\hline & $\mathrm{TR}_{2000} \mathrm{ETL}_{17}$ & & 4.65 \\
\hline & $\mathrm{TR}_{2000} \mathrm{ETL}_{21}$ & & 2.70 \\
\hline
\end{tabular}

\section{B. Discussion}

Time Repetition (TR) is the main parameter in MRI examination. Time Repetition affects the contrast of the MRI image. Prolonged TR administration can examine the tissues in more slices and provide better signal values, but this will also increase the time for image acquisition. Fast TR can shorten data collection time but the number of tissue slices being examined is lower and the signal to noise ratio (SNR) is poor[18],[19]. Time Repetition on Turbo Spin Echo can increase SNR. The parameters that affect image contrast also affect SNR and overall image quality. Changes to the SNR will affect the clarity of anatomic images[18],[19].

Echo Train Length (ETL) is the number of rephasing pulses or $180^{\circ}$ multiple pulses in each TR. The effects of Short ETL on image are increased T1 weighting, decreased effective TE, longer scan time, more slices per TR and reduced image blurring while the effects Long ETL are increased T2 weighting, increased effective TE, reduced scan time, reduced slices per TR and increased image blurring[16],[17].

The results show that the $\mathrm{TR}_{2000}-\mathrm{ETL}_{17}$ combination value is the combination of TR and ETL value that produces the clearest anatomic information images indicated by the highest mean rank for the whole anatomy of the lumbar vertebrae. The $\mathrm{TR}_{2000}-\mathrm{ETL}_{17}$ combination is a value that displays optimal anatomic images because of the trade off or balance achieved value for each combination of TR and ETL[16],[17],[19].

The use of a short ETL will have effects on the images in the forms of increased T1 weighting, decreased effective TE, increased scan time, higher number of slices on each TR and reduced image blurring[17]. The use of long ETL will have effects on increased T2 weighted, increased effective TE, reduced scan time, lower number of slices per TR and increased image blurring[18],[19]. Long TR allows full recovery so that more will experience transverse magnetization on the next RF pulse. A long TR setting will increase the SNR while using a short TR will decrease the
SNR. Higher SNR will make anatomic images clearer[9],[19].

Corpus vertebrae appears to be the clearest with the settings of $\mathrm{TR}_{2000}-\mathrm{ETL}_{17}$, but $\mathrm{TR}_{2000}-\mathrm{ETL}_{21}$ also gives an image of the vertebral body with the same clarity. The use of $\mathrm{TR}_{2000}$ produces the best image on the contrast and sharpness of the image because of the minimal image noise, the use of high ETL will reduce scan time, but this will also decrease the value of SNR resulting in reduced clarity of anatomic information[16],[17]. Intervertebral discs appears to be at the same level of clarity in the $\mathrm{TR}_{2000}-\mathrm{ETL}_{13}$ and $\mathrm{TR}_{2000}-\mathrm{ETL}_{17}$ settings, due to the high contrast and sharpness of the image. The anatomic images of conus medullar appear to be the clearest in the settings of $\mathrm{TR}_{2000}-\mathrm{ETL}_{17}$. The conus medullar is the clearest and the anatomic boundaries are better defined compared to other variations, but the use of TR $1000-\mathrm{ETL}_{17}$ results in clarity of conus medullar that is not different from TR2000-ETL17.

The anatomy of cerebrospinal fluids appears equally well with the use of $\mathrm{TR}_{2000}-\mathrm{ETL}_{13}$ and $\mathrm{TR}_{1000}-\mathrm{ETL}_{17}$. The use of both combination of TR and ETL are able to provide the clearest and sharpest image information compared to other variations of the combination of TR and ETL; however, $\mathrm{TR}_{2000}-\mathrm{ETL}_{17}$ produces images that are not different from the two TR and ETL combinations above. The anatomy of the ligamentum flavum appears the clearest in the settings of $\mathrm{TR}_{2000}$ ETL $_{17}$ compared to other variations of the combination of TR and ETL.

The variation of the $\mathrm{TR}_{2000}-\mathrm{ETL}_{17}$ combination can be used as an alternative to get images with more optimal anatomic information by taking into account the shortest scan time.

The experiment was conducted with the variations of the value of TR and ETL within the range of values that are often found in the service and applicability of patients so that they did not have to spend too much time to conduct the research.

\section{CONCLUSION}

There are differences in anatomic information on variations in the value of the combination of Time Repetition (TR) and Echo Train Length (ETL) on the MRI image of the sagittal lumbar slice with the T2W TSE sequence. The combination of TR and ETL that shows the most optimal lumbar anatomic information is $\mathrm{TR}_{2000}-\mathrm{ETL}_{17}$.

\section{ACKNOWLEDGMENT}

We would like to express our gratitude to the Director of Poltekkes Kemenkes Semarang for facilitating this research. We would also like to express our gratitude to the Director of Naval Hospital Dr. Ramelan Surabaya and Radiology Department for the permission and assistance given during the research process.

\section{REFERENCES}

[1] Riyawan, 2014. Asuhan Keperawatan Medulla Spinalis. FIK Unair. Surabaya

[2] Bogduk, Nikolai. 2005 Clinical Anatomy of the Lumbar Spine and Sacrum; Professor of Pain Medicine, University of Newcastle 
[3] Yueniwati, Y. 2014. Prosedur Pemeriksaan Radiologi Untuk Mendeteksi Kelainan dan Cedera Tulang Belakang; Universitas Brawijaya Press ; Malang

[4] MR Imaging of the Spine at 3.0T with T2-Weighted IDEAL Fast Recovery Fast Spin-Echo Technique) Gambar MRI Lumbal Sagital. Diakses tanggal 25 November 2017

[5] Moeller, Torsten B., M.D. 2003. MRI Parameters and Positioning Georg Thieme Verlag, Rüdigerstraße 14, D-70469 Stuttgart, Germany

[6] Westbrook, Catherine. 2014 Handbook of MRI Technique. Department of Allied Health and Medicine Faculty of Health, Social Care and Education Anglia Ruskin University Cambridge, UK

[7] Moeller. 2003. MRI Parameters and Positioning. Stuttgart: New York

[8] Woodward, Peggy, 2001, MRI for Technologist, McGraw-Hill, Inc, USA

[9] Westbrook, Catherine. 2016 MRI at Glance Third Edition. Department of Allied Health and Medicine Faculty of Health, Social Care and Education Anglia Ruskin University Cambridge, Us

[10] Westbrook, Catherine. and Carolyn Kaut. 2011. MRI in Practice. Fourth Edition. London: Wiley Blackwell.

[11] Nesseth, R. 2000, Prosedure and Documentation for CT and MRI, Mc Graw- Hill, Medical Pulising Division, USA

[12] Simanjuntak, Josepa. 2014. Studi Analisis Echo Train Length Dalam K-Space serta Pengaruhnya Terhadap Kualitas Citra Pembobotan T2 FSE pada MRI 1.5T. Universitas Diponegoro Semarang. Program Studi Magister Ilmu Fisika

[13] Jones, A. Richard, Susan Palasis and J. Damien Grattan-Smith, 2004, MRI of the Neonatal Brain: Optimization of Spin-Echo Parameters, American Journal of Radiology, 182:367-372
[14] Sze G, Kawamura Y, Negishi C, et al. 2003. Fast spin-echo MR imaging of the cervical spine: influence of echo train length and echo spacing on image contrast and quality. AJNR Am J Neuroradiol; 14:1203-13.

[15] Prastowo, Alan Tanjung, dkk, 2013. Korelasi Nilai Time Repetition (TR) dan Time Echo (TE) terhadap Signal to Noise Ratio (SNR) pada citra MRI, Jurusan Fisika, Universitas Diponegoro

[16] Fluid-Attenuated Inversion Recovery Imaging: effect of Varying Effective Echo Time and Echo Train Length. Department of Radiology Duke University. USA.

[17] Notosiswoyo, Mulyono, 2004, Media Litbang Kesehatan: Pemanfaatan Magnetic Resonance Imaging (MRI) Sebagai Sarana Diagnosa Pasien, Volume XIV, Nomor 3

[18] Damanik A.O.Martua, Muchammad Azam dan Muhammad Nuh, 2005, Pengaruh Parameter Teknis TR, TE dan TI Dalam Pembobotan T1, T2 dan Flair Pencitraan MRI, Berkala Fisika, Vol 8 No. 1, hal 1520

[19] Woodward, Peggy and Wiliam, W. Arrison, 2001. MRI Optimization. Ahand on approach. McGraw-Hill. Co. USA

[20] Micheau Antoine, MD. Denis Hoa, MD. 2009. Anatomic Diagrams of The Spine and Back, http://www.imaios.com/en/e-Anatomy /Spine/ Spine-diagrams, diakses tanggal 1 Maret 2019

[21] Wilmink, J.T, 2010 Lumbar Spinal Imaging in Radicular Pain and Related Conditions (C) Springer-Verlag Berlin Heidelberg

[22] Weyreuther, Martin. 2007, MRI Atlas Orthopedics and Neurosurgery the Spine, Rontgenabteilung, HELIOS Klinik Emil Behring, Walterhoferstr, 11, 1465 Berlin 